\section{A geografia médica e as expedições francesas para 0 Brasil: uma descrição da estação naval do Brasil e da Prata (1868-1870)}

\section{Medical geography and the French expeditions to Brazil: a description of the naval station in Brazil and the Prata (1868-1870)}

MORAIS, Rosa Helena de S.G. de. A geografia médica e as expedições francesas para o Brasil: uma descrição da estação naval do Brasil e da Prata (1868-1870). História, Ciências, Saúde Manguinhos, Rio de Janeiro, v.14, n.1, p.39-62, jan.-mar. 2007.

Durante o século XIX, a medicina passou por inúmeras mudanças em seus postulados etiológicos. À geografia médica, disciplina diretamente ligada aos interesses da empresa colonialista européia, coube o mapeamento das doenças em variadas partes do globo. Os médicos das marinhas européias foram encarregados dessa importante missão. Sabia-se que o maior inimigo das tropas e residentes europeus nas colônias e regiões de clima quente eram as doenças ditas tropicais. $\mathrm{O}$ artigo analisa o relatório oficial de viagem de Bourel-Roncière, médico francês responsável pela manutenção da saúde a bordo da embarcação $L a$ Circé, entre os anos 1868-1870. Ressalta o ponto de vista pessoal de Bourel-Roncière a respeito das doenças e seus tratamentos, que ele estudava em colaboração com médicos brasileiros.

PALAVRAS-CHAVE: história da medicina; Estação Naval do Brasil e da Prata; expedições francesas; geografia médica.

MORAIS, Rosa Helena de S.G. de. Medical geography and the French expeditions to Brazil: a description of the naval station in Brazil and the Prata (1868-1870). História, Ciências, Saúde - Manguinhos, Rio de Janeiro, v.14, n.1, p.39-62, Jan.-Mar. 2007.

During the XIX century, medicine went through several etiological postulate changes. Medical geography, the discipline closely tied to the interests of the European colonialist enterprise, was in charge of mapping the diseases occurring all over the world. The physicians in European navies were in charge of this important mission. The greatest enemy of European troops and residents, in the colonies and in the hot climate regions were known to be the so-called tropical diseases. In this article, we analyze the official travel account by Bourel-Roncière, a French physician responsible for healthcare on the ship $\mathrm{La}$ Circé, from 1868 to 1870. Special attention is given to his personal point of view concerning the diseases and respective treatments, which he studied in collaboration with Brazilian physicians.

KEYWORDS: history of medicine; station navale du Brésil et de la Plata; French expeditions; medical geography. 
A história da medicina tem tradicionalmente representado a história do colonialismo europeu como uma luta heróica contra as doenças tropicais. A medicina dirigida para as regiões de clima quente e úmido é tida e justificada como um benefício humanitário concedido pelos países colonizadores, tendo como escopo primordial a legitimação do imperialismo. Dentro dessa mesma vertente, a história da medicina nos trópicos é vista como uma história da raça branca dirigida para um mundo mergulhado na ignorância, na inércia, e devorado por doenças em um ambiente hostil e selvagem. No entanto, nos últimos trinta anos tem sido feita uma crítica dessa visão triunfalista da história do colonialismo europeu. As abordagens são providas de maior criticidade; apontam para uma integração dos diversos aspectos que englobam a problemática e procuram destacar outras facetas, evitando declarações reducionistas e preconceituosas (Arnold, 1993, p.1393-7).

A proposta deste artigo é analisar de forma breve o conteúdo do relatório de Paul Marie Victor Bourel-Roncière, médico militar francês a bordo da Estação Naval do Brasil e da Prata. O conteúdo desse relatório de viagem deve ser interpretado como resultado, entre outros, das preocupações da empresa colonialista européia, que procurava promover e controlar uma rede internacional de pesquisas sobre as doenças e os seus tratamentos. Para compreender completamente essa rede é preciso conhecer o papel desempenhado pelos médicos para fazer frutificar tal empreitada.

Ao longo do século XIX e a favor da empresa colonialista européia, a medicina viu multiplicarem-se os estudos sobre os trópicos. Coube à geografia médica a tarefa de reunir uma gama de conhecimentos sobre as doenças e seu tratamento. A elaboração de um mapa nosográfico implicou, então, um programa de pesquisas médicas amplo e preciso. A tarefa foi desempenhada por centenas de médicos que serviram nas estações navais ancoradas nas diversas costas do globo (Boudin, 1857, p.36).

A geografia médica tinha a preocupação de organizar uma rede de informações médicas, com o propósito de traduzir as muitas definições e tratamentos de doenças para uma linguagem dita científica, que fosse compartilhada por toda a comunidade médica. Os médicos das diferentes marinhas da Europa compunham uma verdadeira falange composta por trabalhadores cujos estudos exigiam plena capacidade profissional. Esses profissionais da saúde teriam sido os únicos capazes de registrar as informações de forma precisa, racional e despersonalizada. Os relatórios oficiais de viagem elaborados por eles foram considerados verdadeiros guias para os exploradores vindouros.

É incontestável que os médicos militares desempenharam um papel muito importante para o sucesso da empresa colonialista européia. Foram pioneiros e observadores privilegiados nos pos- 
tos de observação nas estações navais. Sua presença nos países de clima quente compara-se a verdadeiros laboratórios encravados nesses locais (Curtin, 1996, p.100). Ao mesmo tempo, a presença desses profissionais favoreceu a implementação de um frutífero intercâmbio entre a comunidade científica do Velho Mundo e as comunidades médicas nacionais.

\section{A Estação Naval do Brasil e da Prata: o volumoso relatório do médico Bourel-Roncière}

O ano de 1808 marcou o início de uma nova era para o Brasil, nas suas relações com a Europa. A Colônia veio a abrigar o trono da Corte de Portugal e ganhou sua independência econômica. $\mathrm{O}$ primeiro decreto real do príncipe regente sobre o solo brasileiro, promulgado na Bahia em 28 de janeiro de 1808, abriu os portos brasileiros ao livre comércio com as nações amigas. O decreto de 25 de novembro, completado pela lei de 25 de janeiro de 1809 , deu aos estrangeiros a possibilidade de obter a concessão de terras sesmarias - nas mesmas condições de Portugal. No dia 19 de fevereiro de 1810 foi assinado o tratado de comércio anglo-brasileiro, e um consulado inglês se instalou no mesmo ano no Rio de Janeiro.

No entanto a França foi excluída desses primeiros acordos. As relações belicosas entre o império francês e a coroa de Bragança continuavam marcadas, no território americano, pelo conflito guianês. No dia $1^{\circ}$ de maio de 1808, o príncipe regente declarou guerra à França; a armada brasileira penetrou na Guiana em 3 de dezembro, obrigando o governador Victor Hugues a capitular no dia 12 de janeiro de 1809. Caiena estava nas mãos dos brasileiros. $\mathrm{O}$ Brasil e a França não teriam mais relações diplomáticas nem comerciais até a assinatura do tratado de paz, no ano de 1814.

O primeiro Tratado de Paris, assinado a 30 de maio de 1814, previa a liquidação da questão da Guiana. No dia 18 de junho, o príncipe regente anunciava que as relações diplomáticas com a França seriam retomadas. A influência crescente do ministro Antônio de Araújo de Azevedo, o conde da Barca, contribuiu grandemente para o estabelecimento de um clima d'entente a partir de 1814. As ligações comerciais foram retomadas no final daquele mesmo ano, e o decreto de 18 de novembro estipulou a abertura dos portos do Brasil aos navios e ao comércio francês (Potelet, 1993, p.13-4).

Um dos principais interesses dos dirigentes franceses era desenvolver o comércio com o Brasil. Rapidamente os armadores franceses puderam constatar que o mercado era frutuoso, e assim enviaram cada vez mais navios mercantes para o Atlântico. Para proteger o comércio francês e garantir a segurança dos residentes franceses, o barão Portal, ministro da Marinha e das Colônias, decidiu, em 1821, instalar uma estação naval no Brasil e na região da bacia 
${ }^{1}$ A Station Navale du Brésil et de la Plata adquiriu autonomia em 1841 e, em 1870 juntou-se à Division navale des Côtes Occidentales d'Afrique para constituir a Division Navale de l'Atlantique Sud. A estação seria finalmente dissolvida em 1909, em virtude de uma mudança de interesses por parte da França, que se voltou para a Polinésia e Nova Caledônia em detrimento de seus interesses em países do Atlântico sul
2 Os documentos manuscritos referentes à Station Navale du Brésil et de la Plata encontram-se nos arquivos do Service Historique de la Marine das cidades de Brest (Série FService de Santé) e de Vincennes (Série BB4 - Campagnes; Série CC2 - Officiers civils et corps assimilés ; CC3 Troupes et équipages). A série BB4 comporta inúmeros relatórios dos almirantes franceses, entre os anos de 1865 e 1869 , os quais descrevem minuciosamente $o$ 'teatro da guerra' entre o Paraguai e a Tríplice Aliança, material inexplorado porém precioso para a história desse conflito. do Prata. A partir dessa data, a bandeira francesa não cessaria de tremular nas costas brasileiras. ${ }^{1}$

Em geral, as estações navais tiveram uma presença permanente de navios de guerra e/ou de comércio nas águas americanas e justificavam-se, como dito, pela preocupação em proteger os estrangeiros e preservar o comércio e os interesses nacionais. As forças navais sempre ocuparam um posto privilegiado, e a mobilidade de que gozavam demonstrava sua capacidade de autonomia. Recepções, bailes e representações teatrais eram as ocupações que aproximavam os oficiais da marinha às autoridades locais.

Comparada à Inglaterra, a França começou timidamente, em fins do século XVIII, a colocar estações navais, primeiramente no Mediterrâneo, depois no Extremo Oriente e em seguida nas Antilhas francesas. Havia inúmeras razões, por parte das nações européias, para manter presença constante nas águas da América do Sul. As estações navais, tanto francesas como inglesas, supunham que a costa sul-americana, em especial os portos das cidades de Valparaíso, no Chile, e Calao, no Peru, constituiria os pontos de apoio logístico mais próximos da Oceania (Ortiz Sotelo, 1995, p.5). A França, para concorrer com a Inglaterra, sabia que era preciso espreitar o concorrente mais de perto, verificar 'o que' eles faziam naquelas águas.

A estação naval francesa possuía pequenas embarcações que lhe permitiam navegar pelos grandes rios americanos e lhe garantiam mobilidade em caso de intervenções militares. Ainda que a ordem fosse a de não se envolver nos conflitos locais, a presença desses navios impunha certa respeitabilidade, graças à bandeira francesa e a um reduzido mas potente poder de fogo, cujo objetivo era o de intimidar quando eventualmente necessário. ${ }^{2}$

Dentro desse contexto, confiou-se a Bourel-Roncière o posto de cirurgião-chefe da Estação Naval do Brasil e da Prata, sendo a mesma comandada pelo almirante Fisquet. Entre as diversas incumbências de Bourel-Roncière, figurava a de coletar e analisar, durante dois anos, as condições de higiene do Brasil e do estuário do rio da Prata. A divisão naval estacionada nas costas brasileiras compunha-se, então, de cinco navios: La Circé, Le Bruix, La Décidée, La Fortune e Le Curieux. Paul-Marie-Victor Bourel-Roncière esteve a bordo da fragata La Circé e permaneceu na estação naval do dia 6 de junho de 1868 até o final do mês de agosto de 1870.

O relatório oficial redigido pelo médico chamou a atenção da comissão encarregada de examinar os trabalhos dos oficiais de melhor reputação profissional pertencentes ao Corpo de Saúde da Marinha francesa. Depois da apreciação de oito manuscritos, no dia 14 de dezembro de 1871 a comissão decidiu premiar o memorial de Bourel-Roncière (Bulletin..., 1872). O relatório de viagem foi parcialmente publicado nos Archives de Médecine Navale. 
${ }^{3}$ Esta parte se encontra no Service Historique de la Marine, situado na cidade portuária de Brest, França. O material ainda não foi pesquisado, mas sabese que contém cerca de 350 páginas e é constituído de narrativas sobre a higiene naval, as doenças que acometeram os marinheiros e os tratamentos empregados pelo médico a bordo da embarcação La Circé.

${ }^{4}$ Os trechos de textos em língua francesa citados neste artigo foram traduzidos pela colaboradora.
O manuscrito chamou a atenção pelo volume de 790 páginas e pela importância do seu conteúdo: muitas páginas consagradas à análise do clima, dos rios, da vegetação, das estações climáticas e da relação desses elementos com a produção de doenças no Brasil, sobretudo na cidade do Rio de Janeiro. $\mathrm{O}$ relato divide-se em três partes: a primeira, sob o título Relatório do Conjunto, compreende uma análise sobre as doenças observadas, a causa das mortes a bordo dos navios que compunham a estação e também considerações gerais sobre a higiene, topografia e navegação no rio da Prata e afluentes. Além disso, inúmeros quadros estatísticos resumem toda a análise e apresentam outras informações interessantes, como as variações anuais de temperatura e a pluviometria de toda a região da Prata e do litoral do Brasil.

A segunda parte apresenta um estudo detalhado da topografia médica da cidade do Rio de Janeiro. Também nela encontra-se uma análise dos documentos que tratavam das 'febres' da capital do país. O médico registrou, ainda, suas visitas aos prédios dos principais hospitais da cidade e detalhou as condições de higiene e estrutura física, por meio de dezenas de quadros informativos e estatísticos. Informações sobre os outros hospitais da região da Prata (Montevidéu, Assunção, Buenos Aires) foram aí descritas de forma breve. Os dados sobre outros hospitais do Brasil (Pará, Pernambuco, Bahia e Maranhão) foram fornecidos por outro médico francês da mesma estação, que tinha estado no Brasil entre 1864 e 1866. A terceira parte, enfim, é constituída do relatório médico propriamente dito, da campanha da fragata La Circé. ${ }^{3}$

O médico aportou nas costas do Brasil e da bacia do Prata convencido da existência de problemas de saúde nesses lugares. A posição geográfica seria a principal responsável pela insalubridade. Em suas palavras,

O clima de cada localidade, as influências do solo, os ventos, os átrios infecciosos, as comunicações rápidas, uma imensidão de outras circunstâncias freqüentemente desconhecidas, imprimem ... certas características acidentais ou constantes ... e influenciam normalmente no grau de salubridade, e é por causa disto tudo que ocorrem os mais diversos acidentes patológicos, os perigos ou os benefícios para a saúde ${ }^{4}$. (Bourel-Roncière, 1872a, p.24)

Foi através do estudo do clima e da topografia médica das regiões tropicais que os médicos militares franceses, durante a primeira metade do século XIX, puderam constituir um arcabouço teórico e metodológico sobre as principais doenças que dizimavam soldados, marinheiros, comerciantes e habitantes europeus. Os médicos franceses se orientavam pela literatura advinda das expedições empreendidas no Egito (1798-1801), na Grécia (1829-1831) e na Argélia (1839-1842) e corrigiram os 'equívocos' contidos nos 
5 Jean-Pierre Peter (2004, p.279-282) define constituição médica como o conjunto de condições de uma localidade, como o solo e o clima, que conforme as estações climáticas, os anos e circunstâncias particulares influenciavam sobre a forma e natureza das doenças que afetavam uma determinada região. relatos dos naturalistas e viajantes do século anterior (Osborne, 1996, p.80-98).

Nos relatórios de viagem - de caráter oficial - os médicos descreviam vegetação, clima, solo, hábitos higiênicos dos habitantes de uma determinada região, tudo enfim que pudesse servir como elemento indicador que favorecesse, em primeira instância, a preservação da saúde dos soldados, marinheiros, comerciantes, agricultores e oficiais militares europeus. No entanto, ainda que privilegiassem os cuidados com a saúde das tropas militares e dos residentes europeus, a lógica intervencionista ditava que um coeficiente mínimo de saúde da população local deveria ser garantido, tendo em vista o contato permanente desta última com os europeus (Arnold, 1993, p.1398).

Por certo não se deve atribuir à medicina praticada nos trópicos a exclusiva responsabilidade pelo sucesso da colonização européia, mas as informações fornecidas pelos médicos tornaram as conquistas menos custosas (Curtin, 1996, p.99-107). Ao chegar a uma localidade, verificavam nos hospitais a quantidade de leitos e condições de ventilação e higiene, a localização de farmácias, o número de salas destinadas às cirurgias e o tratamento aplicado pelos médicos locais em caso de epidemia, com o objetivo primeiro de garantir a saúde e o bem-estar da tripulação dos navios ali estacionados.

Os relatórios de viagem incluíam descrições dos tratamentos das doenças e feridas, com inúmeras referências aos princípios hipocráticos. Nesses manuscritos pode-se observar a utilização de uma vasta gama de produtos laxativos, tais como óleo de rícino, magnésio, pílulas vegetais, depurativos, elixires e chocolates medicinais, que serviam para favorecer a excreção dos fluidos corporais.

Os médicos tomavam os enunciados hipocráticos como base para a elaboração da topografia médica de uma região, do estudo da influência dos ventos e solo, da dieta alimentar e dos hábitos locais. As informações permitiam conhecer a constituição médica ${ }^{5} \mathrm{de}$ uma região e a natureza das doenças, e podia-se, assim, prescrever a terapêutica apropriada. Essa medicina neo-hipocrática estruturava-se essencialmente pela observação evolutiva das doenças e se ocupava do reconhecimento dos sintomas.

No relatório do médico Bourel-Roncière algumas recomendações referentes à higiene naval seguiam os princípios hipocráticos applicata, gesta e ingesta. Podemos entender applicata como uma escolha adequada na maneira de se vestir conforme às estações climáticas. Os médicos deveriam observar também, segundo essa regra, os exercícios e as atividades corporais. Havia discordâncias sobre a maneira como os europeus deveriam se vestir nos países tropicais. Nem todos os médicos, por exemplo, estavam de acordo sobre o tempo que um marinheiro poderia expor-se ao sol e a forma de fazê-lo. Alguns defendiam que a exposição às correntes de ar fresco 
favorecia um resfriamento e poderia mesmo suprir a transpiração, provocando por conseqüência embaraços intestinais. Para BourelRoncière, o corpo deveria estar bem protegido por vestimentas adequadas que evitassem a exposição aos raios solares. Mas apesar de todas as divergências, a grande maioria dos médicos concordava que, ao se exporem a uma secreção anormal, os indivíduos poderiam sucumbir à influência nociva do clima tropical.

Por gesta entendia-se o controle do excesso de exercícios musculares. Assim, os médicos estavam sempre atentos para que o serviço a ser executado pela tripulação estivesse em consonância com as regras adequadas de higiene. Era preciso observar as condições climáticas e evitar os trabalhos e o cansaço excessivos, bem como uma longa exposição aos ardores dos raios solares. O descarregamento de navios efetuava-se, não raro, depois do pôr-do-sol, a fim de prevenir os acidentes patológicos. Essas medidas de caráter empírico contribuíram para diminuir os riscos de insolação e de desidratação.

Por ingesta compreendia-se a observação contínua da alimentação. Existia um cuidado com o aporte de víveres frescos e também com o excesso alimentar, regras estas correntemente quebradas pelos marinheiros de bordo. Outra importante medida higiênica consistia na verificação, ao chegar a uma localidade, da existência de rios e poços nas proximidades a fim de fornecer água doce para a tripulação. Os filtros forneciam água boa, mas não se podia garantir que era potável, destituída de germes patogênicos. A filtração era lenta, o gosto e a cor da água não agradavam aos homens. Era função do médico preocupar-se com a pureza da água e com o seu fornecimento. As diarréias eram comuns a bordo, e não raro atribuídas ao calor e à umidade do hemisfério sul.

Um dos triunfos da medicina do século XIX foi a prevenção de doenças, o que nos faz pensar sobre a preocupação dos médicos com a pureza da água. Mesmo baseados em conceitos empíricos, os tratamentos e as medidas higiênicas contribuíram enormemente para a diminuição da mortalidade. Uma das causas mais freqüentes de mortes foi justamente a ingestão de água impura. Pode-se então afirmar que, a partir das primeiras descobertas de germes patológicos, houve maior compreensão sobre os mecanismos de funcionamento dos filtros de areia - os mais comumente utilizados na época -, o que viabilizou a fabricação de filtros mais eficazes e seguros. Os resultados desse passo puderam ser percebidos nas estatísticas médicas, que acusavam uma considerável redução do número de mortes provocadas por febre tifóide e gastroenterite (Curtin, 1995, p.111). Filtros eficazes, vestimenta adequada, higiene corporal - a medicina naval caminhou lenta mas firmemente durante o século XIX. 


\section{A exuberante e insalubre cidade do Rio de Janeiro}

O texto de Bourel-Roncière apresenta tal riqueza de detalhes que nos estimula a fazer um passeio imaginário pelas ruas do Rio de Janeiro dos anos de 1868 a 1870. Sempre fazendo eco aos princípios hipocráticos, o médico descreve primeiramente a topografia da cidade e seus arredores, procurando em seguida estabelecer um vínculo entre os aspectos geográficos e a incidência de certas doenças.

Segundo Bourel-Roncière, os navios de diversas expedições estrangeiras estavam em geral submetidos às variações de temperatura e a um conjunto de influências mórbidas comuns a todas as regiões de clima quente. As localidades consideradas mais insalubres de toda a costa brasileira, do ponto de vista desse médico, eram Rio de Janeiro, Bahia e Pernambuco. Esses locais eram tidos como verdadeiros antros de infecção e estavam sujeitos a longos períodos epidêmicos, apresentando um perigo constante para todas as embarcações. As temperaturas elevadas do Rio de Janeiro e da Bahia obrigavam as tripulações estrangeiras em expedição a tomar rígidas medidas higiênicas, com a finalidade de amenizar a ação debilitante do calor.

As medidas higiênicas empreendidas pelo médico BourelRoncière consistiam em evitar, a priori, todas as comunicações fora do ambiente da embarcação. As saídas para terra eram proibidas, a não ser em casos indispensáveis. Os passeios ou trabalhos em dias de intenso calor eram desaconselhados à tripulação, a fim de poupá-la dos efeitos da insolação. Durante a noite, as saídas deviam ser evitadas por causa dos cabarés que margeavam as praias, onde os marinheiros podiam procurar, a baixo preço, as 'águas perniciosas'.

As doenças mais freqüentes dependiam normalmente do gênero de vida e da ocupação dos marinheiros e oficiais, ou dos hábitos por eles cultivados. O médico sabia de antemão que, quando um navio se deslocava de um porto para outro, a concessão dos passeios noturnos em terra resultava quase sempre no aparecimento de doenças venéreas alguns dias depois da partida (Léonard, 1967, p.96). Durante os períodos de epidemias, a regra absoluta era fugir mais rapidamente possível dos locais infectados. No entanto, se o navio fosse forçado a permanecer em uma localidade infectada, todas as comunicações com a terra eram proibidas, exceto em situações de extrema necessidade. A quantidade de serviço de bordo era reduzida e proibia-se o repouso fora das tendas e baterias do navio, de modo a preservar ao máximo os homens da ação solar (Bourel-Roncière, 1872a, p.27-41). Em suma, as medidas higiênicas se resumiam a dois pontos básicos: limpeza e aeração dos navios.

A definição da higiene como disciplina remonta ao modelo de intervenção que vigorava sobre a vida privada e pública 
(Rasmussen, 2001, p.213-239). A partir do final do século XVIII, a desodorização dos corpos e do espaço constituiu o apanágio das preocupações dos médicos higienistas. Mais importante era assegurar a circulação do ar, a fim de escapar da 'estagnação mórbida'. A ventilação garantia a qualidade anti-séptica do ar; o movimento atmosférico provocava a agitação das águas que, juntamente com o ar em constante movimento, favoreciam a purificação e asseguravam a salubridade do ambiente (Corbin, 1982, p.105-118). Barcos, hospitais e prisões funcionavam como verdadeiros laboratórios, onde se instituíram técnicas de ventilação e desinfecção. Uma aeração enérgica, para fornecer uma quantidade de ar respirável e para secar a umidade, constituía uma medida higiênica capital, para o médico Bourel-Roncière (1872a, p.114):

Lavar ... aerizar, ventilar, secar e fazer penetrar o ar em todos os lugares e constantemente, é um procedimento que deve ser sempre seguido pelo comandante-chefe dos navios da estação naval; estas medidas podem ser consideradas como uma primeira condição para manter a saúde da tripulação ... uma boa ventilação e a existência de fortes correntes de ar são um meio eficaz contra o calor excessivo.

Outro aspecto continuamente observado pelos médicos em expedição era a presença de hospitais nas cidades e as suas condições higiênicas. Os registros de Bourel-Roncière sobre os hospitais têm relação, primeiramente, com a saúde dos marinheiros, soldados, oficiais - doentes ou feridos - da estação naval, em caso de epidemia local.

A autoridade dos médicos europeus e sua responsabilidade no 'diagnóstico' de um país era tarefa das mais importantes para o andamento da empresa colonialista. Suas opiniões sobre as condições gerais dos hospitais, as doenças mais comuns, o número de funcionários - médicos, farmacêuticos e enfermeiros - disponíveis, as despesas hospitalares, a arquitetura do prédio e os tratamentos correntemente utilizados pelas comunidades médicas locais, serviam como verdadeiros guias às autoridades governamentais e, conseqüentemente, a outros médicos exploradores. BourelRoncière elaborou um texto com inúmeros detalhes sobre os principais hospitais brasileiros, sobretudo os da cidade do Rio de Janeiro, com o intuito de conhecer a fundo o funcionamento da assistência hospitalar do país. Seus objetivos, explicitados no início do relato, evidenciam-se no grande número de documentos reunidos para seus sucessores na Divisão Naval, que assim disporiam de "informações necessárias e precisas para melhor executar o serviço" (Bourel-Roncière, 1872a, p.185). O esboço histórico mais bem detalhado foi o da Santa Casa da Misericórdia, em virtude da impor- 
tância do hospital para a população e por localizar-se na capital do país. Quando se fazia necessário, como em caso de doença grave a bordo ou em época de epidemias, os socorros se executavam naquele hospital.

A arquitetura do prédio da Santa Casa da Misericórdia foi considerada magistral e comparada à dos estabelecimentos europeus. A localização do prédio, às margens do mar, dotava os quartos dos doentes da brisa marítima, tida como indispensável à saúde dos indivíduos. Como já dissemos, os médicos da época consideravam primordial uma boa ventilação do espaço, pois evitava a estagnação do ar e os 'miasmas nauseabundos'. Para garantir boa aeração, era preciso observar os espaços entre as camas, a quantidade de janelas e o espaço entre elas, o tamanho dos corredores e a existência de grandes jardins para o passeio dos doentes. Essas seriam algumas das condições necessárias para viabilizar a salubridade de um hospital. Todas as considerações sobre o hospital da Misericórdia, positivas ou negativas, foram comparadas sobretudo às dos hospitais franceses, tidos como modelos de salubridade.

Manter o ambiente arejado mas sobretudo seco, era a premissa fundamental para Bourel-Roncière, no que concernia à higiene nosocomial. Assim, do ponto de vista do médico, a situação geográfica do hospital era inadequada, visto que, construído ao pé do morro do Castelo, seu terreno baixo favorecia a umidade, a qual, por sua vez, beneficiava a propagação de doenças. A fachada do prédio próxima ao litoral ficava exposta durante todo o dia aos ventos marítimos, que, mesmo favorecendo a boa aeração dos corredores, eram muito frios e carregados de umidade (Bourel-Roncière, 1872 b, p.216). Para o autor, a despeito do luxo no acabamento do prédio do hospital, com "magníficos granitos do Rio de Janeiro e madeira mais nobre do Brasil", a higiene hospitalar deixava muito a desejar.

Segundo os preceitos de higiene da época, a localização de um hospital era elemento importante para a manutenção de suas condições higiênicas. Sobre esse aspecto, as pesquisas efetuadas por Lavoisier no final do século XVIII, acerca do ar respirado no ambiente hospitalar, foram de extrema relevância, pois serviram para revelar a composição química do ar atmosférico, descoberta que muito influenciou a prática médica. Lavoisier dedicou-se ao estudo de uma série de questões relativas à natureza das emanações produzidas pelo homem em estado de saúde e de doença, como também indicou precauções que deviam ser tomadas para neutralizar ou mesmo dirimir a perigosa influência dessas emanações (Boisseau, 1888, p.287). Os médicos e higienistas insistiam em que os hospitais fossem construídos de maneira a não anular o efeito salutar do ar. Entretanto, se o hospital da Santa Casa da Misericórdia não era tido como um modelo exemplar de construção hospitalar, tampouco 
o eram certos hospitais europeus. Na França, os médicos propalavam "os princípios de higiene nosocomial, mas os administradores e os arquitetos obstinavam-se em cometer erros antigos" (p.287).

O médico francês Fondère, em seu Traité d'hygiène publique et de médecine légale, resumiu claramente o pensamento da época sobre o tema:

Supondo-se que eu fosse bastante feliz em fundar um hospital, eu o construiria sobre um lugar seco, elevado e com uma vizinhança próxima às fontes de água corrente, e ainda sobre um plano suficientemente inclinado. No lugar, eu ainda gostaria de ter um jardim onde os doentes pudessem passear. Os quartos seriam elevados, espaçosos e com muitas e amplas janelas situadas em todas as paredes... (citado em Boisseau, 1888)

Eram essas algumas das condições que, reunidas, satisfariam as exigências de uma boa higiene hospitalar, mas que nem todos os hospitais europeus conseguiam seguir à risca.

Retomemos o relatório de Bourel-Roncière. Na segunda parteconsagrada, conforme mencionado, ao clima do Rio de Janeiro e às doenças que comumente acometiam a população local -, o médico esclarece que seus estudos tinham como objetivo a construção de um escopo de dados estatísticos e informativos sobre as condições climáticas gerais às quais estava submetida a tripulação da estação naval no Rio de Janeiro (Bourel-Roncière, 1872b, p.321). Descreve o aspecto geográfico do Rio de Janeiro e constata que a cidade situa-se em uma imensa planície, cercada de morros que formam um cinturão ao seu redor. O morro do Castelo, berço da cidade de São Sebastião, era coberto de florestas luxuriantes e imensos terrenos pantanosos. A situação é considerada desfavorável do ponto de vista higiênico, em virtude da quase perpendicularidade dos morros em relação aos ventos, o que representa um obstáculo à ventilação. O médico economiza elogios ao analisar a topografia da capital, deixando de lado os qualificativos triviais de 'cidade pitoresca como uma pintura', com uma 'costa bela e mágica', para melhor caracterizá-la: "[A cidade] situava-se numa espécie de vale circunscrito por duas linhas de colinas e ... todas estas elevações, na periferia ou mesmo no meio da planície, apresentavam incontestáveis obstáculos à ventilação dos bairros".

Dessas condições resultaria o calor predominante nas ruas do Rio, as quais considera, por sua vez, mal distribuídas e estreitas. Nada é feito para combater o calor existente. As ruas da cidade velha não se abriam para a passagem da brisa marítima, e a região privava-se de uma ventilação eficaz. Já nas ruas da cidade nova reinavam os "antros pestilenciais e os depósitos de imundícies". As praias da Saúde e da Gamboa, do saco do Alferes e a praia Formosa serviam de depósito de detritos. Os pântanos de São Cristóvão eram 
um lugar de "vastas planícies negras e fétidas". Os "eflúvios dos pântanos" de Botafogo, quando sopravam os ventos vindos do sul, atingiam os navios ancorados no porto da capital. Durante o verão os miasmas atingiam um enorme grau de nocividade, à qual se submetia a tripulação dos navios (Bourel-Roncière, 1872b, p.326-333).

As palavras do médico Bourel-Roncière alinham-se ao discurso da maioria das autoridades médicas e políticas brasileiras da época. Os pântanos e certos morros que faziam parte da paisagem do Rio de Janeiro eram considerados os principais agentes responsáveis pela insalubridade da cidade. O arrasamento dos morros e a drenagem dos pântanos eram recomendações antigas, que visavam destruir os eflúvios miasmáticos emanados desses lugares. As autoridades médicas desejavam arrasar o morro do Castelo e alguns outros para garantir a circulação das pessoas e a aeração das ruas pelos ventos marítimos, cuja ausência era diretamente associada à incidência de epidemias que aterrorizavam a população local e os estrangeiros. No início do século XX (1904), o morro do Castelo foi parcialmente arrasado para permitir a abertura da avenida Rio Branco. No entanto traços dele ali permaneceram, contrastando com o Museu Nacional de Belas Artes, a Biblioteca Nacional e outras imponentes construções da Belle Époque carioca. Essa história já foi bastante documentada e existem muitos trabalhos de geógrafos, historiadores, arquitetos, antropólogos e urbanistas sobre a evolução urbana da cidade do Rio de Janeiro. O debate interdisciplinar em que participam as diversas abordagens contribui para enriquecer a história do arrasamento do morro do Castelo e vem a ser uma forma de preservar o passado e o patrimônio cariocas.

Mas o que verdadeiramente importa para o nosso trabalho é observar a retórica controversa dos discursos de médicos estrangeiros que aportavam na cidade. Alguns deles apresentavam um panorama mágico da costa carioca, suas "belas árvores, florestas imponentes ... e tão majestosa planície às margens da qual se estendia a grande e bela cidade do Rio" (Bourel-Roncière, 1872b, p.345). Outra visão muito difundida harmonizava-se com a opinião de Bourel-Roncière, para quem o paludismo se escondia por detrás daquela "barreira de beleza exótica".

Assim, a causa predisponente de diversas epidemias e endemias foi associada aos elementos atmosféricos. O calor e a umidade constantes faziam parte das características topográficas da cidade tropical, situada em uma imensa planície no nível do mar e cercada de montanhas elevadas, cujas inúmeras fontes de rios inundavam a parte baixa e formavam planícies pantanosas. Esses pântanos transformavam-se em depósito de matérias orgânicas em decomposição. As águas estagnadas que evaporavam dali contaminavam o ar com 
emanações miasmáticas. Os morros impediam a circulação de ar e conseqüentemente a sua renovação e os miasmas palustres permaneciam inertes sobre a cidade, predispondo sua população para diversas doenças.

A incidência de determinadas moléstias associava-se à vaga noção de miasmas, palavra mal definida mas correntemente utilizada para descrever a corrupção do ar (Hannaway, 1993, p.292-308). A natureza ou mesmo o caráter dos miasmas, ainda que confusos, eram relacionados às fontes de putrefação do ar, que incluíam os pântanos com suas águas estagnadas, os vapores que emanavam dos corpos humanos e dos animais em decomposição, as excreções e as emanações pútridas das latrinas. Essa definição geral dos miasmas guardou força e perdurou durante todo o século XIX (p.295).

As autoridades médicas divergiam quanto aos elementos atmosféricos serem causadores de doenças ou fatores que predispunham os indivíduos a elas. Parte dessa divergência deve-se ao sucesso no emprego das medidas higiênicas. A maioria das autoridades médicas, como Lévy, Sigaud, Celle e Foissac, defendia que as doenças tinham como causa principal a organização individual. Havia no indivíduo fatores intrínsecos - temperamento, idiossincrasias, hábitos, constituição, idade, sexo e hereditariedade - que favoreciam $\mathrm{o}$ acometimento de moléstias. $\mathrm{O}$ clima, tido como agente produtor de males, era uma hipótese de valor relativo, porém alguns médicos admitiam que o conjunto de agentes do circunfusa encontrava um ponto considerado optimum no meio quente e úmido (Lévy, 1844, p.82-84).

Bourel-Roncière reconhece os esforços da administração local na higiene e manutenção da limpeza das ruas e praças da cidade. No entanto o médico não se cansa de afirmar que, apesar de todas as medidas e cuidados com a purificação da cidade, não se poderia anular a influência das 'febres' existentes nos vastos terrenos pantanosos que cercavam o Rio de Janeiro e atuavam sobre suas condições meteorológicas. O clima e a umidade excessiva, a abundância de terrenos baixos e inundados, os milhares de cursos d'água que cortavam a imensa costa eram as causas do "princípio palustre reinante em todos os lugares". A capital do país era, sob o olhar do médico, "um antro repleto de terrenos suspeitos, de lugares infectados pelo sangue e restos de animais que as pessoas matavam diariamente; lugar povoado de falanges de urubus que aí viviam, morriam e se decompunham - sobretudo nas baías, se estendiam pântanos sem fim localizados por detrás das altas montanhas e morros". Tudo era considerado um antro de exalações pestilenciais e febres intermitentes.

Bourel-Roncière, citando Broussais, observa também a mobilização do governo brasileiro no combate às doenças de origem 
palustre que inflamavam o Rio de Janeiro e as vizinhanças, sobretudo a febre tifóide, endêmica no país. Mas os médicos brasileiros são duramente criticados porque, a despeito de conhecerem a natureza e a origem infecciosa da doença, "com uma certa timidez ... seguiam os preceitos do mestre [Broussais] e as doutrinas da época; e com uma certa apreensão aconselhavam o sulfato de quinina, os tônicos, as poções amargas, as evacuações e as sangrias, algumas gotas de vinho seguido de caldos de galinha ou de boi", resultando em alta mortalidade populacional (Bourel-Roncière, $1872 b$, p.343).

Em suma, o médico francês expressa uma visão um tanto pessimista a respeito da região:

... a condição palustre dominará para sempre no quadro nosológico da cidade, mesmo com as constantes mudanças na topografia do Rio que aconteciam nos últimos quinze anos ... os melhoramentos que aí podem ser vistos ainda assim não são suficientes para mudar as características de planície baixa, plana, de aluvião e, é de se esperar que sua atmosfera jamais seja purificada da influência dos terrenos pantanosos de Macacu, Magé, Iguaçu e de outros lugares da costa que serão sempre antros de exalações malsãs que os ventos carregam para dentro da cidade... (Bourel-Roncière, 1872b, p.343)

\section{Fundamentos e controvérsias da geografia médica}

As autoridades médicas européias sabiam que, nas regiões tropicais e colônias, o verdadeiro inimigo do médico, do explorador, do soldado, da administração colonial e dos habitantes europeus era a doença tropical. A febre tifóide, a malária e sobretudo a febre amarela eram os flagelos mais temidos pelos europeus, sendo responsáveis pela maioria das mortes nos trópicos. Durante muito tempo, os médicos atribuíram aos trópicos um número significativo de doenças , por considerá-los locais patogênicos por excelência (Naraindas, 1994, p.31-56). O clima quente, a umidade, o excesso da flora e fauna, bem como a imundície foram atributos correntemente utilizados para distinguir os trópicos de outras regiões do mundo.

Um ponto de controvérsia entre as autoridades médicas da épo-

6 Segundo Jousset (1888, p.6-68), o termo aclimatamento consistia no emprego de medidas higiênicas com o objetivo de promover a adaptação física e moral dos indivíduos em um novo ambiente. ca refere-se à questão da capacidade de aclimatamento ${ }^{6}$ dos europeus ao clima tropical. Para uns, os trópicos eram uma verdadeira imagem do purgatório travestido em paraíso (Anderson, 1996, p.6267). Uma crença, alimentada pela literatura de viagem e estatística médica, sustentava ser o clima dos trópicos um elemento de influência funesta sobre a saúde dos indivíduos, contribuindo para degenerar as qualidades do homem branco europeu. Para os médicos e para a administração colonial, o estudo da capacidade de 
aclimatamento dos europeus era condição fundamental para o avanço da empresa colonialista. A opinião de Armand, ex-médico chefe do hospital militar de Saigon, a propósito da aclimatação representa a versão comumente difundida no meio científico da época:

a transferência para um país de clima quente se fará geralmente sem problemas, se o emigrante estiver em boas condições de vida ... ou seja, desenvoltura e bem-estar, se o mesmo indivíduo for sedentário; mas [a transferência] será desastrosa e até mortal para aqueles que estiverem na miséria e condenados aos trabalhos de campo, ou seja, sob a influência ardente e nociva do clima quente. (Armand, 1873, p.822)

Os europeus utilizavam comumente certas regiões consideradas menos insalubres como estação de aclimatamento. A administração colonial francesa enviava suas tropas à ilha da Reunião, no oceano Pacífico, antes de transferi-las para a Argélia. A prática visava fomentar a imunidade dos soldados e oficiais contra algumas doenças tropicais.

A geografia médica dependia da coleta de informações por parte de observadores situados em diversos pontos do globo. Esses observadores deviam trabalhar sobre uma base de dados comum e sob uma mesma metodologia. Em seguida, uma vez coletadas, as informações deveriam ser comparadas e analisadas detalhadamente. A execução dessa árdua tarefa não se fazia sem dificuldades, e um interminável debate ocorria, entre as autoridades médicas, sobre a melhor forma de coletar, comparar e analisar as informações. Era preciso construir uma mesma nomenclatura nosológica, reunir uma enorme gama de informações sobre uma localidade e, com máximo rigor científico, procurar estabelecer gradualmente, no curso dos anos, uma homogeneidade do conteúdo pesquisado, tarefa que exigia esforço concentrado por parte das autoridades médicas.

Os médicos militares, ansiosos por estabelecer os fundamentos da geografia médica, criticavam continuamente os estudos pouco sistemáticos e sobretudo equivocados que entravavam o desenvolvimento da disciplina. Chefe da clínica do hospital de Brest (França), J. Mahé ilustra bem o pensamento dos médicos militares metropolitanos quando defende que, para fazer avançar a elaboração de um mapa nosológico, era preciso criticar as "denominações de doenças edificadas sobre os preconceitos populares, sobre a rotina da medicina local ... dogmas de escolas, sobre doutrinas recém-descobertas e, logo generalizadas". A crítica do médico dirigia-se a alguns de seus colegas médicos que faltavam com o rigor necessário à elaboração de uma nomenclatura patológica clara e uniforme. Os militares reivindicavam para si a missão de reunir "os médicos de todos os países e de todos os tempos", a fim de estabelecer uma linguagem científica comum em relação às diversas doenças (Mahé, 1882, p.386). 
Jean-François-Xavier Sigaud, em sua célebre obra Du climat et des maladies du Brésil ou statistique médicale de cet Empire, desacreditava os registros patológicos coletados pelos viajantes naturalistas como fonte de conhecimento sobre clima e doenças. Para Sigaud, era preciso lançar um olhar crítico sobre esses relatos, repletos de narrativas pomposas e exageradas. Devia-se passar ao lado dos quadros poéticos, ter ainda muita paciência diante das descrições obrigatórias sobre os perigos do cotidiano para, ao final de uma longa leitura, conseguir encontrar alguns poucos fatos verdadeiramente científicos sobre o clima e as doenças de uma localidade. Sigaud condenava esse modelo de narrativa e assinalava existir nele uma quantidade ínfima de relatos sobre doenças, os quais eram apenas ecos de crenças tradicionais que repousavam sobre tratamentos populares e raramente apresentavam um diagnóstico verdadeiro das doenças (Sigaud, 1844, p.2).

Jules Rochard, diretor do serviço marítimo francês do porto de Brest, ao exaltar a missão dos médicos militares também dirigiu críticas aos 'antigos' e atribuiu-lhes certos equívocos, como a falta de uma observação precisa e a ausência de conhecimentos anteriores, o que fazia a imaginação transportá-los às mais altas esferas da metafísica. Os viajantes não teriam, portanto, o hábito de manter "os pés sobre o chão" (Rochard, 1868, p.308).

Os sábios viajantes e as instituições metropolitanas foram desacreditados diante da autoridade dos médicos militares. Para certos expoentes da medicina, o estabelecimento de fatos e teorias médicas não poderia fornecer frutos preciosos se não fosse executado pelos médicos militares em expedição nas colônias e regiões tropicais, e somente o uso da estatística médica e uma observação clínica rigorosa poderiam sedimentar os fundamentos da geografia médica (Le Roy de Méricourt, 1864).

Uma contraposição a esse discurso pode ser feita, já que era correntemente recomendado aos viajantes, filósofos e naturalistas dos séculos XVII e XVIII que, em suas viagens, estivessem munidos de instrumentos, efetuassem observações e tomassem medidas. Já se observa, no final do século XVII, uma preocupação relacionada ao transporte de barômetro, mapas, telescópios e demais instrumentos que pudessem servir para tomar medidas e elaborar cálculos. Para efetuar corretamente as observações físicas e meteorológicas, eram preferíveis os números e as medidas às anotações pitorescas, pois existia, já então, forte preocupação com a precisão dos dados informacionais.

Cada vez mais os instrumentos de pesquisa evoluíam em busca da precisão e tendiam a englobar o conhecimento sobre a natureza. O viajante apercebeu-se da necessidade de, depois das observações cotidianas dos fenômenos, comparar as medidas e submetê-las 
a uma confrontação com os dados coletados simultaneamente por outros viajantes. A questão do aperfeiçoamento dos instrumentos e comparação das medidas apareceu no horizonte das experiências dos viajantes e revelou, no último terço do século XVIII, a problemática da padronização dos dados. Os sábios ambicionavam encontrar uma regra constante por intermédio da observação precisa dos fenômenos. A comparação dos dados trouxe à tona um elemento importante, referente à coordenação das operações de medidas e ao estabelecimento de uma rede de intercâmbio entre os viajantes com vistas à padronização. Tal ambição revela a existência de uma "dinâmica centrífuga, expansionista, consagrada a dominar o espaço físico, fazer aumentar os limites do mundo conhecido e impor ainda o domínio dos números - precisos, estáveis - espalhando-os até as regiões inexploradas onde antes prevaleciam os mitos, as fábulas e as lendas" (Bourguet Licoppe, 1997, p.1115-151).

A maneira de relatar e descrever do viajante daquela época se inscreve em um quadro de inteligibilidade particular e corresponde a uma concepção diversa da natureza. Os registros iconográficos e os relatos de viagem descreviam a variedade dos elementos de um lugar de forma exaustiva e aprofundada. Para executar um relato de viagem era preciso utilizar técnicas da retórica e da arte. Desse modo, a descrição das sensações deveria levar a uma aproximação da realidade percebida. Para os viajantes, a multiplicidade das sensações podia e devia ser descrita pela ciência.

Em síntese, o novo contexto mostrava que a retórica utilizada pelos médicos militares impunha uma 'ruptura' com a tradição centenária dos viajantes naturalistas, cujas narrativas haviam sido, até então, as principais fontes de informação sobre as 'regiões exóticas'. Esse discurso representava uma mudança em relação às práticas anteriores tanto quanto uma busca pela legitimidade profissional. Os médicos militares sustentavam que os antigos observadores careciam de precisão, instrumentos e conhecimentos preliminares, exigidos à redação de relatórios de viagem. Uma nova realidade se impunha, e o médico explorador que servia nas colônias e regiões tropicais passou a ocupar um papel central no novo contexto.

Se anteriormente os conhecimentos médicos sobre determinada região somente podiam ser obtidos por meio de uma viagem científica, da observação direta ou ainda em contato com as autoridades médicas locais (Edler, 1999, p.67-70), os periódicos representaram, no novo cenário, importante fonte e veículo de difusão das pesquisas médicas e científicas. Nas suas páginas o debate científico ganhou uma nova dimensão. Os periódicos permitiram trocas científicas e encorajaram debates fora do espaço institucionalizado das escolas de medicina. Pode-se compará-los a embarcações que possibilitaram a união entre os continentes, favoreceram a circulação das 
idéias e contribuíram, assim, para diminuir as distâncias entre países e cientistas. E graças à troca dinâmica que promoveram, os periódicos viabilizaram a uniformização de certos conceitos científicos.

Löwy chama a atenção para um movimento dirigido à internacionalização da ciência, ocorrido por volta dos anos de 1880, o qual representou uma reação ao espírito nacionalista que estimulava a divisão e a atomização da atividade científica. Desde o século XVII os cientistas identificavam-se à nação a que pertenciam, e o século XIX assistiu a uma tensão permanente entre os diferentes particularismos nacionais e o universalismo científico, edificada sobre tradições profissionais e ideológicas (Löwy, 2001, p.31).

O ideal universalista científico dessa época encontrou um espaço fértil e fundamental nas páginas de periódicos. Os Archives de Médecine Navale, periódico francês fundado em 1864, exemplifica essa voga universalista. Contribuiu para a padronização das informações nosológicas e veio a ser um dos fóruns de autoridade médica, reunindo em suas páginas um circuito científico de escala mundial. Os saberes puderam nele circular de forma ampla e diversificada. Um dos propósitos desse periódico era o de difundir o máximo de informações sobre as regiões que atraíam o interesse das políticas imperialistas, o que acabou por favorecer intercâmbios científicos que permitiram a formação de um conhecimento sobre clima, vegetação e doenças de inúmeras regiões do globo. De fato, suas páginas abrigaram grande número de trabalhos científicos de médicos franceses e estrangeiros, que tratavam, em geral, das patologias humanas de diferentes regiões não-européias.

O periódico era dirigido por Le Roy de Méricourt, professor da Escola de Medicina de Paris e oficial da Légion d'Honneur. Méricourt defendia que os Archives deveriam ocupar-se dos escritos considerados lacunares ou das informações perdidas, atinentes a questões essenciais para o funcionamento do serviço colonial europeu, entre as quais os temas predominantes eram as condições sanitárias e nosológicas das regiões tropicais e colônias (Le Roy de Méricourt, 1864, p.7). Em outras palavras, esse rude trabalho deveria resultar em uma espécie de guia médico das costas do mundo inteiro. Certamente haveria lacunas, além de imperfeições, mas o projeto serviria de ponto de partida para outros médicos. Aos poucos e graças a um esforço concentrado, o serviço de saúde da marinha, cujos estudos mereciam plena confiança, poderia erguer uma obra durável sobre climatologia e patologia exóticas (p.8-9).

A experiência francesa com os Archives de Médecine Navale não foi a única. Iniciativas semelhantes foram tomadas também por países como a Inglaterra, com o Annual Statistical Reports, e os Estados Unidos, com o National Board of Health Bulletin. Na Alemanha também houve publicações dedicadas à nosologia geográfica, como o periódico Mittheilungen von Petermnn, e na Itália publicaram-se 
alguns periódicos sobre geografia médica, a exemplo do Geographia Nosologica dell'Italia (Mahé, 1882, p.385). Mas o periódico francês teve o mérito de colocar em evidência aspectos considerados obscuros e controversos da patologia e nosologia. A rede de pesquisas médicas por ele estabelecida reforçou a autonomia e a autoridade dos médicos da marinha e do exército francês. Esse poderoso instrumento organizou e definiu o papel da geografia médica na esfera médica.

Os Archives de Médecine Navale criaram, também, uma espécie de fronteira entre o médico que trabalhava na colônia e aquele da metrópole. O discurso corrente era o de que somente os médicos militares da marinha dos diferentes países, servindo nas colônias e em várias partes do globo, estariam aptos a realizar o programa da geografia médica, ou seja, organizar um mapa nosológico do mundo inteiro. Os 'médicos de gabinete' não teriam os meios necessários para obter informações sobre os trópicos, visto que as doutrinas médicas européias se mostravam incoerentes quando confrontadas com a realidade das regiões tropicais. Jean Pierre Thévenot, diretor do serviço médico militar na Argélia entre os anos de 1836 e 1840, admitia que somente médicos que trabalhavam nas zonas tórridas possuíam a capacidade de elaborar uma descrição das doenças e estudar os "países de clima quente" (Thévenot, 1840).

\section{A geografia médica e o 'espírito pasteuriano'}

É emblemática a institucionalização da medicina tropical no final do século XIX, quando a disciplina aliou-se às outras que emergiam no meio médico: helmintologia, protozoologia, parasitologia e bacteriologia (Edler, 1999, p.95). Freqüentemente associa-se a efervescência da medicina tropical ao nascimento da 'ciência pasteuriana'. É bem verdade que as primeiras descobertas bacteriológicas tiveram atuação primordial no desenvolvimento da medicina tropical, no entanto esta disciplina nutriu-se, no momento de sua institucionalização, da teoria dos germes, acrescentando ainda ao seu domínio de estudo a noção de distribuição geográfica das doenças (Worboys, 1976, p.75-98). Anne-Marie Moulin (1996, p.95) reforça esse argumento e assinala que a medicina tropical participou do novo espírito pasteuriano, o qual preconizava que as doenças eram resultado da pululação dos germes - seres vivos microscópicos - e não mais da putrefação, como se acreditava anteriormente.

As regiões de clima quente e úmido foram um campo fértil para o desenvolvimento da medicina, uma vez que os médicos puderam observar as doenças infecciosas e seus tratamentos preventivos e curativos (Löwy, 2001, p.14). O estudo das doenças ditas tropicais e seus tratamentos culminou com a institucionalização 
da medicina tropical como disciplina. Ao mesmo tempo, o saber médico beneficiou-se da aparição de um novo paradigma médico, no qual o parasita, tido como vetor de doenças, representou um papel importante.

Moulin (1996, p.9-13) afirma que o entusiasmo científico, ligado ao desejo de aperfeiçoar a mão-de-obra e proteger os colonos contra as doenças locais, impulsionou a fundação das principais escolas de medicina tropical. Esse entusiasmo trouxe novos conceitos científicos às pesquisas sobre as regiões tropicais. $\mathrm{O}$ controle dos vetores de certas doenças foi possível graças ao desenvolvimento da microbiologia, no entanto não se deve esquecer que existia, antes da ciência pasteuriana, uma medicina dos climas quentes já bastante desenvolvida.

Entre as muitas discussões que têm alimentado essas novas abordagens, uma delas chama a atenção para um ponto crucial: o sentido polissêmico da palavra 'tropical', permeada de metáforas e a evocar uma enorme gama de reflexões. A região do norte da África, por exemplo, que se estende pelo Trópico de Câncer e se localiza na zona temperada, é um bom exemplo, tendo em vista que não apresenta as características atrativas e repulsivas normalmente associadas às zonas tropicais (Moulin, 1996, p.160-180). Mesmo assim, o termo 'tropical' coincidiria com a palavra 'colonial', carregando em si uma conotação pejorativa.

O aspecto geográfico do termo 'tropical' é, assim, o exemplo mais ilustrativo da complexidade de fatores que envolvem a metáfora da região dos trópicos. Essa metáfora indica a existência de um rígido determinismo em relação aos habitantes dos trópicos, ao clima e ao fator geográfico. À palavra 'tropical' são associadas a pobreza e a miséria fisiológica. O discurso médico veiculado sobretudo em fins do século XVIII e durante o século XIX mostra que esses profissionais - convencidos da superioridade da medicina européia - traduziam os trópicos como lugar privilegiado para a produção de doenças (Arnold, 1993, p.1393-1397).

Se compreendermos a medicina tropical num sentido mais amplo, como uma medicina especializada no estudo das zonas tórridas, com literatura e prática específicas e constituindo, portanto, um domínio do saber integralmente ligado à empresa colonialista européia, a qual aspirava a um controle sobre a maioria das regiões do globo, então poderemos remontar a um período bem anterior à história das conquistas européias (Arnold, 1996, p.2). Isto significa refletir sobre a ação dos médicos militares das diversas marinhas da Europa, os quais lutavam para assentar os pilares da geografia médica como disciplina. 


\section{Considerações finais}

As reflexões do médico Bourel-Roncière, mesmo carregadas de conotação negativa, são ricas em detalhes sobre a topografia e as principais doenças que acometeram a população do Rio de Janeiro. O discurso do médico nutriu-se das estatísticas médicas da época, que apresentavam um desconcertante panorama nosológico da cidade. Esse discurso serviu para alimentar durante muitos anos certo preconceito quanto aos países de clima quente e úmido.

O relatório do médico não deixa de ser emblemático, pois o volume de detalhes revela o universo das publicações consagradas às expedições médicas militares e à geografia médica durante o século XIX, assuntos estes pouquíssimo abordados na literatura brasileira.

As críticas emitidas por Bourel-Roncière revelam também um universo permeado de controvérsias científicas que agitavam o meio médico na época, e mostram a existência de uma competição entre as diversas correntes cognitivas. Trechos do relatório do médico podem levar a crer que os tratamentos para certas doenças por ele ministrados eram 'mais científicos' do que os empregados pelos médicos brasileiros. Esse tipo de julgamento não é cabível. Ao contrário; a lógica que regia a medicina daquela época era diferente da observada em fins do século XIX. Os tratamentos aplicados aos doentes deveriam obedecer a uma determinada coerência. $O$ médico deveria agir segundo o bom senso, de modo a não prejudicar ou aumentar ainda mais o sofrimento alheio. A recorrência às autoridades médicas da época era um fenômeno comum e tinha por finalidade a legitimação da prática e dos discursos empregados. BourelRoncière menciona, em seu relatório, renomados médicos franceses como Boudin, Broussais, Sigaud e Fonssagrives, mas também autoridades médicas locais como Moncorvo de Figueiredo e O. Wucherer.

De modo geral, independentemente da autoridade médica que emitia um enunciado, a medicina praticada nos trópicos, nos primeiros anos do século XIX, tinha uma racionalidade particular. Essa medicina dos climas quentes ocupava-se dos sintomas das doenças, flagelos misteriosos que desolavam cidades inteiras. Era uma medicina que acreditava nos miasmas nauseabundos a emanar dos pântanos e produzir enfermidades, uma medicina com profunda consideração pelos pressupostos de T. Sydenham (1624-1689). Em fins do século XIX, quando abundavam relatos das maravilhas da nascente era bacteriológica, os relatórios dos médicos descreviam tratamentos nos quais vacinas e sangrias ocupavam o mesmo patamar.

Uma outra reflexão de caráter mais geral que pode advir do estudo do relatório de Bourel-Roncière é que, mesmo antes das primeiras descobertas bacteriológicas, certas medidas higiênicas baseadas 
na observação contínua da topografia, do clima e dos costumes de uma região serviram para promover uma queda considerável no número de mortes de soldados e habitantes (Curtin, 1995). A distribuição de carnês de higiene privada às tropas, a instalação de mecanismos para escoamento das águas e dejetos, a filtragem da água, a maneira de se vestir e a dieta alimentar foram medidas empíricas que muito contribuíram para esse fenômeno.

Em suma, a institucionalização da medicina tropical como disciplina, em fins do século XIX, teve como conseqüência a modificação da hierarquia ocupada pelos agentes do meio ambiente na produção de doenças. Os agentes meteorológicos passaram para o grupo dos atores secundários; de causa eficiente para causa predisponente. Mas tudo isso ocorreu de maneira gradual, e antigas autoridades da geografia médica tiveram de recuar diante dos novos protagonistas. Os pressupostos dessa disciplina foram revistos e os micróbios roubaram a cena sem, contudo, desprivilegiar os fatores ambientais como elementos que favoreciam a produção de doenças.

\section{BIBLIOGRAFIA}

Anderson, Warwick 1996

Armand, Adolphe 1873

Arnold, David (Org.) 1996.

Arnold, David 1993

Bertillon, Louis A. 1864

Boisseau 1888

Boudin, J. Ch. M. 1857

Bourguet, Marie-Noëlle; Licoppe, Christian 1997

Bourel-Roncière, Paul Marie Victor 1873 $1872 \mathrm{a}$
Diseases, race, and empire. Bulletin of the History of Medicine, Baltimore. v.70, n.1, p.62-67.

Traité de climatologie générale du globe. Études médicales sur tous les climats. Paris: G. Masson Éditeur.

Warm climates and Western medicine: the emergence of tropical medicine, 1500-1900. Amsterdam: Rodopi.

Medicine and colonialism. In: Bynum, William F.; Porter, Roy. (Org.). Companion encyclopedia of the history of medicine. London: Routledge. p.1393-1416.

Acclimatement. In: Dechambre, Amédée (Org.). Dictionnaire encyclopédique des sciences médicales. Série 1 (1864-1888), tome 1. Paris: G. Masson, Asselin et Houzeau. p.270-323.

Hôpitaux. In: Dechambre, Amédée (Org.). Dictionnaire encyclopédique des sciences médicales. Série 4 (1877-1889), tome 14. Paris: G. Masson, Asselin et Houzeau. p.273-425.

Traité de géographie et de statistique médicale et des maladies endémiques comprenant la météorologie et la géologie médicales, les lois statistiques de la population et de la mortalité, la distribution géographique des maladies et la pathologie comparée des races humaines. Paris: J.-B. Baillière et fils.

Voyages, mesures et instruments: une nouvelle expérience du monde au siècle des Lumières. Annales. Histoire, Sciences Sociales, Paris, v.52, n.5, p.1115-1151.

La station navale du Brésil et de la Plata. Archives de médecine navale, Paris, v.19. 
Bourel-Roncière, Paul Marie Victor

Bourel-Roncière, Paul Marie Victor $1872 \mathrm{~b}$

Bulletin... 1872

Congresso... 1890-1892

Corbin, Alain. 1982

Curtin, Philip D. 1996

Curtin, Philip D. 1995

Dechambre, Amédée 1864

Edler, Flávio Coelho 1999

Fonssagrives, Jean Baptiste 1876

Hannaway, Caroline 1993

Jousset, Alfred 1888

Léonard, Jacques 1967

Le Roy de Méricourt, Alfred 1864

Lévy, Michel 1844

Löwy, Ilana 2001

Mahé, Jean Baptiste 1882

Moulin, Anne Marie (Org.) 1996

Naraindas, Harish 1994
La station navale du Brésil et de la Plata. Archives de médecine navale, Paris, v.17.

La station navale du Brésil et de la Plata. Archives de médecine navale, Paris, v.18.

Bulletin officiel: dépêches ministérielles concernant les officiers du corps de santé de la marine. Archives de Médecine Navales, Paris, v.17, p.76-77.

Congresso Brasileiro de Medicina e Cirurgia do Rio de Janeiro, 2. Anais... Rio de Janeiro: Imprensa Nacional.

Le miasme et la Jonquille: l'odorat et l'imaginaire social, $\mathrm{XVIII}^{\mathrm{e}}-\mathrm{XIX}^{\mathrm{e}}$ siècle. France: Flammarion.

Disease and imperialism. In: Arnold, David (Org.). Warm climates and Western medicine: the emergence of tropical medicine, 1500-1900. Amsterdam: Rodopi. p.99-107.

Death by migration: Europe's encounter with the tropical world in the nineteenth century. Cambridge: Cambridge University Press.

Introduction. In : Dechambre, Amédée (Org.). Dictionnaire encyclopédique des sciences médicales. Série 1 (1864-1888), tome 1. Paris: G. Masson, P. Asselin. p.I-XLVIII.

A constituição da medicina tropical no Brasil oitocentista: da climatologia à parasitologia médica. Tese (Doutorado) - Instituto de Medicina Social, Universidade do Estado do Rio de Janeiro, Rio de Janeiro.

Climats. In : Dechambre, Amédée (Org.). Dictionnaire encyclopédique des sciences médicales. Série 1 (1864-1888), tome 18.

Paris: G. Masson, P. Asselin. p.13-121.

Environment and miasmata. In: Bynum, William F.; Porter, Roy (Org.). Companion encyclopaedia of the history of medicine. London: Routledge. p.292-308.

De l'acclimatement et de l'acclimatation. Archives de Médecine Navale. Paris, tome 40, p.6-68.

Les officiers de Santé de la marine française de 1814 à 1835.

Paris: Librairie C. Klincksieck.

Introduction. Archives de Médecine Navale.

Paris, tome 1.

Traité d'hygiène publique et privée.

Paris: J.-B. Baillière. 2v.

Virus, moustiques et modernité.

Paris: Ed. des archives contemporaines.

Géographie médicale. In : Dechambre, Amédée (Org.). Dictionnaire encyclopédique des sciences médicales. Série 4 (1877-1889), tome 8.

Paris: G. Masson, P. Asselin. p.1-400.

Médecines et santé. v.4.

Paris: Unesco. p.9-13.

A genealogy of the advent of tropical medicine.

In: Moulin, Anne-Marie (Ed.). Médecines et santé. v.4. Paris: Unesco. p.31-56. 
Ortiz Sotelo, Jorge 1995

Osborne, Michael A. 1996

Peter, Jean-Pierre 2004

Potelet, Jeanine 1993

Rasmussen, Anne 2001

Rochard, Jules 1868

Sigaud, Jean François Xavier 1844

Thévenot, Jean Pierre F. 1840

Trindade, Etelvina Maria de Castro 2001

Worboys, Michael 1976
America y Oceanía en el juego de las potencias matitimas, siglos XVIII y XIX. Trabalho apresentado no Coloquio America y Oceanía. Lima. Disponível em: http://derroteros.perucultural.org.pe/nume4.shtml.

Resurrecting Hippocrates: hygienic sciences and the French scientific expeditions to Egypt, Morea and Algeria. In: Arnold, David (Org.). Warm climates and Western medicine: the emergence of tropical medicine, 15001900. Amsterdam: Rodopi. p.80-98.

Constitution médicale. In: Lecourt, Dominique (Org.)

Dictionnaire de la pensée médicale. Paris: Puf. p.279-282.

Le Brésil vu par les voyageurs et les marins français, 1816-1840. Paris: Éditions L'Harmattan.

L'hygiène en congrès (1852-1912): circulation et configuration internationales. In: Bourdelais, Patrice (Org.). Les hygiénistes: enjeux, modèles et pratiques. Paris: Belin. p.213-239.

De l'influence des climats sur l'homme, et des agents physiques sur le moral. Archives de Médecine Navale, Paris, tome 9, p.302-308.

Du climat et des maladies du Brésil ou statistique médicale de cet empire. Paris: Chez Fortin, Masson et Cie, Libraires.

Traité des maladies des européens dans les pays chauds, et spécialement au Sénégal, ou Essai statistique, médical et hygiénique, sur le sol, le climat et les maladies de cette partie de l'Afrique. Paris: J.- B. Baillière.

Modèles et emprunts : l'hygiénisme au Brésil (fin $\mathrm{XIX}^{\mathrm{e}}-$ début $\mathrm{XX} \mathrm{C}^{\mathrm{e}}$ siècles). In: Bourdelais, Patrice (Org.) Les hygiénistes: enjeux, modèles et pratiques. Paris: Belin. p.267-295.

The emergence of tropical medicine: a study in the establishment of a scientific speciality. In: Lemaine, Gerard (Org.) Perspectives on the emergence of scientific disciplines. London: The Hague.

Recebido para publicação em fevereiro de 2005.

Aprovado para publicação em fevereiro de 2006. 